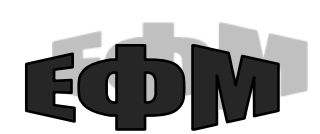

http://efm.vsau.org/

ПРИХНО Ирина Николаевна - доктор экономических наук, доцент, доцент кафедры финансов, Черкасский государственный технологический университет (18006, бул. Шевченко, 460, Черкассы, Украина, ira.prikhno@gmail.com).

ЧАСТОКОЛЕНКО Игорь Павлович - кандидат физико-математических наук, доцент, доцент кафедры высшей математики и информационных технологий, Институт пожарной безопасности им. Героев Чернобыля Национального университета гражданской защиты Украины (18000, ул. Оноприенка, 8, Черкассы, Украина, igor.chft@gmail.com).

МАРЧЕНКО Артем Павлович - преподаватель кафедры высшей математики и информационных технологий, Институт пожарной безопасности им. Героев Чернобыля Национального университета гражданской защиты Украины (18000, ул. Оноприенка, 8, Черкассы, Украина, apbkafmat@gmail.com).

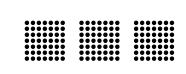

УАК 33.076:378(73)

\section{ТЕНАЕНЦІї КРЕАИТУВАННЯ ВИЩОї ОСВІТИ В США $\odot$}

о.М. ДЖЕДЖУЛА, доктор педагогічних наук, професор, Вінницький національний аграрний університет (м. Вінниця)

У статті висвітлюються механізми освітнього кредитування у США. Виступаючи прибутковим сектором економіки, система освітнього кредитування забезпечує доступність вищої освіти та отримання у майбутньому стабільної роботи для американської молоді. Проведено аналіз залежності загальних витрат на вищу освіту від валового внутрішнього продукту. Розглянуто причини високого попиту на освітні кредити у США. Проведено порівняльний аналіз найбільш поширених видів кредитних програм: федеральної, приватної та батьківської. 3'ясовано умови надання кредитів студентами кожної з програм, переваги федерального кредитування порівняно з іншими видами надання освітніх кредитів, умови надання кредитів іноземним студентам. Проаналізована тенденџія щуодо зменшення освітніх кредитів для студентів. Серед причин зменшення студентських кредитів виокремлено різке зростання заборгованості за студентськими кредитами.

Ключові слова: кредитування, освітній кредит, освітне кредитування, кредитна заборгованість, вища освіта, фінансування вищої освіти.

Табл.: 1. Рис.: 2. Літ.: 12.

\title{
TRENDS OF HIGHER EDUCATION LENDING IN THE USA
}

\author{
DZHEDZHULA Olena, \\ Doctor of Pedagogical Sciences, Professor, \\ Vinnytsia National Agrarian University
}

(Vinnytsia)

The article examines the mechanisms of educational lending in the United States. The system of educational lending is a profitable sector of the economy and ensures the availability of American youth to higher education and acquisition of stable employment in the future. The analysis of the dependence of the general expenses on higher education on GDP is carried out. The reasons for the high demand for educational loans in the United States are considered. A comparative analysis of the most common types of credit programs 
- federal, private and parental - is conducted. Conditions for granting loans by students of each of the programs, the advantages of federal lending in comparison with other types of educational loans, conditions for granting loans to foreign students are clarified. The tendency of reduction of educational credits for students is analyzed. Among the reasons for reducing student loans, a sharp increase in student loan indebtedness was noted.

Key words: lending, educational credit, educational lending, credit indebtedness, higher education, financing of higher education.

Tabl.: 1. Fig.: 2. Ref.: 12.

\section{ТЕНДЕНЦИИ КРЕДИТОВАНИЯ ВЫСШЕГО ОБРАЗОВАНИЯ В США}

\section{ДЖЕДЖУЛА Елена Михайловна, доктор педагогических наук, профессор, Винницкий национальний аграрный университет}

(2. Винница)

В статье освещаются механизмы образовательного кредитования в США. Выступая прибыльным сектором экономики, система образовательного кредитования обеспечивает доступность американской молодежи к высшему образованию и получению в будущем стабильной работы. Проведен анализ зависимости общих расходов на выстее образование от ВВП. Рассмотрены причины высокого спроса на образовательные кредиты в США. Проведен сравнительный анализ наиболее распространенных видов кредитных программ: федеральной, частной и родительской. Выяснены условия предоставления кредитов студентами каждой из программ, преимущества федерального кредитования по сравнению с другими видами предоставления образовательных кредитов, условия предоставления кредитов иностранным студентам. Проанализирована тенденщия уменьшения образовательных кредитов для студентов. Среди причин уменьшения студенческих кредитов выделено резкий рост задолженности по студенческим кредитам.

Ключевые слова: кредитование, образовательный кредит, образовательное кредитование, кредитная задолженность, высшее образование, финансирование высшего образования.

Табл.: 1. Рис.: 3. Лит.: 12.

Постановка проблеми. Кредитування вищої освіти у світі та в Україні набуває все більшої популярності. За статистикою майже $60 \%$ студентів українських ЗВО навчається на контрактній основі. Підвищення плати за навчання, погіршення фінансового стану родин і прагнення молоді отримати вищу освіту створює протиріччя, одним із шляхів подолання якої $є$ навчання у кредит.

У розвинених країнах відпрацьовані механізми освітнього кредитування, що забезпечують потребу молоді у здобутті освіти. Варто зазначити, що освітні кредити є ефективними у країнах 3 високоякісними системами освіти, які надають майбутньому випускнику надійну гарантію працевлаштування та стабільну заробітну плату. США відносять до 7 країн з найкращими освітніми системами. Тому актуальним для пошуку механізмів кредитування студентської молоді в Україні $\epsilon$ дослідження тенденцій кредитування освіти у провідних країнах світу i, зокрема, у США.

Аналіз останніх досліджень та публікацій. Науковці приділяють значну увагу дослідженню освітнього кредитування у США. Фінансова підтримка вищої освіти у США розглядається в працях Стойки О.Я. [1]. Романовський О.О. аналізує фінансовий аспект державної політики США щодо підтримки розвитку вищої освіти [2], проблеми вищої освіти США висвітлюються у працях Тарасової О.В. [3], Калініної О.В. [4] та інших науковців. Методичні підходи оцінки ефективності кредитних відносин досліджуються у працях Л.О. Вдовенко [5].

Різні аспекти фінансових проблем вищої освіти у США з'ясовуються у працях Floyd D. L. [6], Rivka A. F. [6], Ramdin G. [6], Gatto J.T. [7], Jeynes W. H. [8] та інших дослідників.

Проте питання з'ясування механізмів та причин нестабільності надання освітніх кредитів у США ще не знайшли достатнього висвітлення у дослідженнях науковців.

Формулювання цілей статті. Мета статті полягає у дослідженні особливостей та перспектив розвитку освітнього кредитування в США.

Виклад основного матеріалу дослідження. Аналіз тенденцій кредитування вищої освіти в США дає можливість створення науково обгрунтованих моделей системи освітнього кредитування 


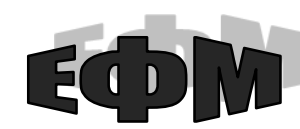

http://efm.vsau.org/

в Україні. Тому для визначення векторів проведення дослідження вважаємо доцільним коротко охарактеризувати механізми надання кредитів на освіту в нашій країні.

За останні роки в Україні спостерігається зменшення прямого кредитування освіти. Банківські кредити на освіту фактично замінюються споживчими кредитами. Особливість такого кредитування для українських абітурієнтів полягає в тому, що споживчі кредити дозволено видавати лише особам старше 25 років. Отже, банківський кредит можуть отримувати батьки майбутнього студента. Порівняно з кредитом на освіту, процедура отримання споживчого кредиту є більш спрощеною: не потрібна довідка про вступ до ЗНО, шкільний атестат. Проте освітній кредит має як певні переваги, так і певні недоліки (таблиця 1).

\section{Переваги та недоліки освітнього кредиту порівняно із споживчим кредитом}

Таблиия 1

\begin{tabular}{|c|c|}
\hline Переваги освітнього кредиту & Недоліки освітнього кредиту \\
\hline $\begin{array}{l}\text { 1. Видається на тривалий термін (до } 11 \\
\text { років, а за наявності державної субсидії цей } \\
\text { термін може бути збільшений) }\end{array}$ & $\begin{array}{l}\text { 1. Банк може припинити перерахування грошей } 3 \\
\text { одночасним продовженням нарахування відсотків } \\
\text { (наприклад, якщо студента призвали на військову } \\
\text { службу) }\end{array}$ \\
\hline від 10 до 20\%) & $\begin{array}{l}\text { 2. При відрахуванні студента банк може } \\
\text { збільшити відсоткову ставку }\end{array}$ \\
\hline $\begin{array}{l}\text { 3. Можливість погашення кредиту після } \\
\text { закінчення навчання }\end{array}$ & 3. Вимагається наявність договору із ЗВО \\
\hline $\begin{array}{l}\text { 4. Можливість перерахування кредиту тран- } \\
\text { шами (наприклад, кожний семестр - } 1 \text { транш) } \\
\text { та припинення кредитної лінії (наприклад, при } \\
\text { поліпшенні фінансового стану) }\end{array}$ & $\begin{array}{l}\text { 4. Кредит можна отримати лише після вступу до } \\
\text { ЗВО }\end{array}$ \\
\hline
\end{tabular}

Джерело: сформовано автором

Як видно з таблиці, освітні кредити мають значну привабливість для студентів, але поруч із цим слабке державне регулювання негативно впливає на розвиток системи освітнього кредитування в Україні. Натомість у США система освітнього кредитування контролюється державою і має достатньо розгалужену структуру.

Витрати на освіту у будь-якій країні залежать від ВВП. Аналіз діаграми (рис.1) підтверджує стабільне зростання ВВП у США. Наведені на діаграмах дані щодо 2019 і 2020 років $є$ прогнозованими [8].

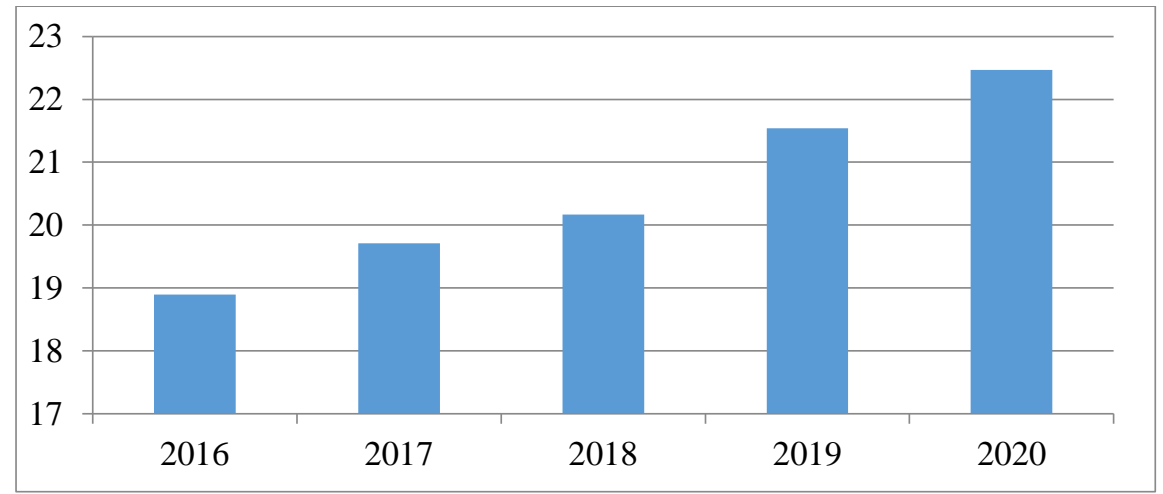

Рис.1. Зростання внутрішнього валового продукту США, трлн дол. США

Джерело: узагальнено автором з використанням [9]

Видатки на освіту загалом та на вищу освіту також збільшуються (рис. 2).

Проте аналіз витрат на освіту та вищу освіту засвідчує певну стабільність видатків на освіту у відсотках відносно ВВП. Порівняно з 2016 роком цей показник у 2017 і 2018 роках збільшився на $0,1 \%$ і становив $5,1 \%$. У 2019 році прогнозується збільшення видатків також на $0,1 \%$, а у 2020 році - на $0,2 \%$. 


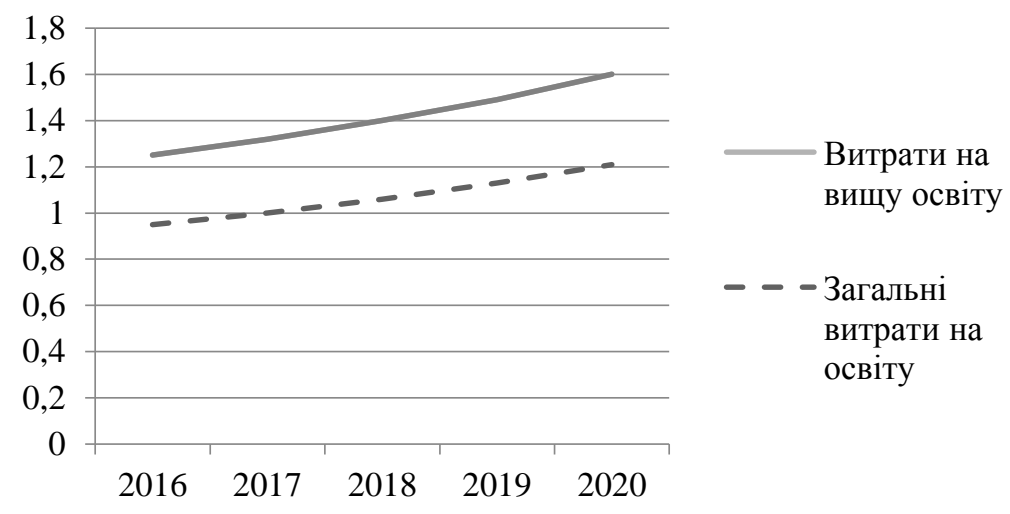

\section{Рис. 2. Загальні витрати в США на освіту та вищу освіту, трлн дол. США Джерело: узагальнено автором з використанням [9]}

Показник видатків на вищу освіту відносно ВВП також не має різко вираженої тенденції до зростання. У 2016 році загальні витрати на вищу освіту у відсотках до ВВП становили 1,7\%, а у 2017 і 2018 роках цей показник знизився до 1,6\%. У 2019 і 2020 роках видатки на вищу освіту відносно ВВП прогнозуються на рівні 2016 року (тобто 1,7\%).

Такий стан фінансування освіти призводить до підвищення плати за навчання та актуалізує питання кредитування освіти. Основною причиною збільшення плати за навчання економісти вважають інфляційні процеси, які є невід'ємною частиною ринкової економіки. Середня плата за навчання у 2018 році зросла на 250 доларів США (на 2,5\% відповідно до рівня інфляції (2,9\%) у 2017 році). При цьому середні федеральні виплати на одного студента скорочувались. Отже, можна впевнено прогнозувати збільшення плати й у наступні роки [10].

У США освітні кредити залишаються одним із найприбутковіших секторів банківської діяльності. 32019 року випускники американських шкіл, що вступили до коледжів та університетів, за 4 роки навчання повинні внести суму, що приблизно дорівнює 130 тисячам доларів. Така сума вважається достатньо високою навіть для середньостатистичного громадянина, адже за даними американського Бюро офіційної статистики у 2018 році 113,4 млн штатних працівників та службовців у середньому за місяць отримали 3820 доларів (до сплати податків) [10]. батьківський.

У програмах кредитування освіти США можна виокремити 3 види: федеральний, приватний,

Найбільшим попитом користуються федеральні кредити. Найбільш популярними видами кредитів на освіту сьогодні вважають кредит Стаффорда (Stafford Federal Student Loan) і кредит Перкінса (Federal Perkins Loans For College Students). Середня сума кредиту становить 21 тисячу доларів. Найважливішою перевагою цих продуктів є можливість його погашення після того, як випускник університету почне працювати. Порівняно з кредитами на освіту в Україні, кредитна ставка для американських студентів значно нижча і становить 5-7\%, а термін погашення кредиту може сягати 30 років. Особливістю цих кредитів $є$ те, що вони видаються не лише на освіту студента, але й на його прожиття. При федеральному кредитуванні поручителем студента $є$ уряд США, який установлює відсоткову ставку (як правило, у межах 4-8\% річних) і страхує банки, що працюють з освітніми кредитами. Механізм федерального кредитування можна вважати достатньо оптимальним для студента: не враховується платоспроможність позичальника (для студентів 3 низьким рівнем доходу навіть пропонуються більш сприятливі умови); виплати за федеральними кредитами дозволяється відкладати і в окремих випадках припиняти виплату до 6 місяців; транші видаються на термін від 10 до 12 років; надається можливість консолідувати кредит, виплачуючи його протягом 30 років. Проте федеральні кредити надаються лише громадянам США або легальним іммігрантам.

Федеральний освітній кредит Стаффорда більш поширений. Його перевагами вважається низька відсоткова ставка і гнучка система погашення. Проте отримати максимальну суму кредиту можна лише за умови відповідності вимогам цієї програми: успішність, навчання за повною програмою, позичальник має бути громадянином США. 


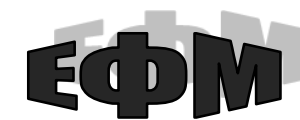

http://efm.vsau.org/

Експерти вважають, що значний відсоток студентів не отримує федеральні кредити внаслідок недостатньої інформаційної підтримки федеральних програм освітнього кредитування та формальностей їх оформлення [6,7].

Спрощена процедура приватних студентських кредитів сприяє їх активному поширенню. Приватні кредитори працюють безпосередньо 3 позичальниками i особисто зацікавлені у поширенні цього виду банківського продукту.

За приватними кредитами потрібно виплачувати вищі відсотки. Отримати приватний кредит складніше, ніж федеральний: поручителем має бути громадянин США, потрібне підтвердження доходу.

Батьківське кредитування передбачає отримання кредиту батьками, які несуть відповідальність за його цільове використання та виплати банку. Особливостями банківського кредиту є такі: необхідність довести платоспроможність; термін кредиту, як правило, до 10 років; виплата кредиту починається через 2 місяці після його отримання; під час навчання можна виплачувати лише відсотки за користуванням кредитом. Для порівняння наведемо наступні дані: кількість позичальників, що отримали батьківські кредити у 2017-18 рр., становила 12\% від числа студентів, які отримали субсидовані і несубсидовані прямі позики, але середній розмір позики для батьків склав 16450 дол. США, що у 2,5 разу більше, ніж середній розмір позики для студентів [12].

Для фінансування іноземних студентів доступний приватний кредит Private International Student Loan. Позика видається інвесторами і кредиторами, в ролі яких можуть виступати банки.

Такий сприятливий клімат кредитування освіти створився завдяки цілеспрямованій державній політиці уряду США. Зауважимо, що ефективні умови освітнього кредитування розповсюджуються й на іноземних студентів, хоча й за певних умов: потрібно довести наявність стабільного доходу (власного або батьків); мати у якості поручителя громадянина США або легального резидента; одним із гарантів має бути навчальний заклад США.

Незважаючи на системну державну політику США щодо надання освітніх кредитів в опублікованих звітах ради коледжів за 2018 рік вказується на зменшення освітніх позик за останні 7 років. Студенти та їх батьки позичили 105,5 млрд доларів США у 2017-2018 роках порівняно 3 127,7 млрд доларів США у 2010-2011 роках. Обсяг федеральних кредитів на одного студента також скоротився у 2017-18 роках сьомий рік поспіль - з 5830 дол. США (в доларах 2017 року) у 20102011 роках до 4510 дол. США у 2017-18 роках. Федеральні позики на одного аспіранта FTE скоротилися з пікового рівня у 19180 дол. США у 2010-2011 роках до 17340 дол. США у 20142015 роках, після чого зросли до 17990 доларів [10].

Причинами зменшення освітніх кредитів потрібно вважати проблеми у погашенні заборгованостей. Станом на березень 2018 року 52\% непогашеної заборгованості за федеральні кредити на освіту становили 14\% позичальників на суму 60000 доларів США і більше; 56\% позичальників з непогашеною заборгованістю заборгували менше 20000 доларів.

Заборгованість за студентськими кредитами посідає друге місце у структурі кредитних заборгованостей американців і перевищує 1,4 трлн доларів [12], що негативно впливає на економіку США.

Висновки. США мають найбільш розвинену систему освітнього кредитування, яка виступає потужним стимулом отримання вищої освіти, забезпечує іiі доступність верствам населення 3 різним рівнем доходів. Для студентів пропонується три види освітніх кредитів: федеральний, приватний і батьківський. Найбільш низькі відсотки можливо отримати за федеральним освітнім кредитом. Останні 3 роки характеризуються зменшенням освітніх кредитів. Причинами, що призвели до зниження використання федеральних кредитів, стали недостатня поінформованість студентів про цей вид кредитування, посилення контролю за виконанням умов домовленостей за кредитом. Надання освітніх кредитів у США пов'язується із різким зростанням заборгованостей за ними, що може привести до фінансової кризи. Тому розробка механізмів їх повернення стає економічною проблемою, яка потребує нагального вирішення. Зростання плати за навчання в українських вищих навчальних закладах освіти зумовлює необхідність впровадження позитивного досвіду США у наданні студентських освітніх кредитів. Перспективним вважаємо спрощення процедури надання студентських кредитів за американською моделлю. Зважаючи на особливості соціальних відносин в українському суспільстві, привабливими в умовах зростання плати за навчання стане батьківський вид кредитування. Перспективи подальших досліджень ми пов'язуємо із вивченням програм списання освітніх боргів у США. 


\section{Список використаних джерел}

1. Стойко О.Я. Фінансова підтримка вищої освіти в США. Науковий вісник Ужсгородського наиіонального університету. 2014. №.29. С.213-216. URL: https://dspace.uzhnu.edu.ua_(дата звернення: 14.02.2019).

2. Романовський О.О. Державна політика США і Великобританії щодо підтримки розвитку вищої освіти. Державне управління: удосконалення та розвиток. 2015. № 12. URL: http://www.dy.nayka.com.ua_(дата звернення: 22.02.2019).

3. Тарасова О. Вища освіта в США: сучасний стан та пріоритети розвитку. Вісник Наиіональної академії Державної прикордонної служби України. 2011. №3. URL: http ://nbuv.gov. ua/UJRN/Vnadps_2011_3_9 (дата звернення: 02.03.2019).

4. Калініна О.Г. Система управління якістю освіти у ВНЗ США: дис. ... канд. екон. наук: 08.0014 . Старобільск: ДЗ ЛНУ ім. Т.Шевченка, 2015. 168 с.

5. Вдовенко Л.О. Методичні підходи оцінки ефективності кредитних відносин. Економіка та суспільство. 2018. №17. C.518-523. URL: http://economyandsociety.in.ua_(дата звернення: 04.03.2019).

6. Floyd, D. L., Rivka, A. F., \& Ramdin, G. A retrospective of four decades of community college research. Community College Journal of Research and Practice. 2015. Vol.40. №1. P.5-22. DOI: https://www.tandfonline.com / doi/abs/10.1080/10668926. 2015.1086707/ (дата звернення: 21.02.2019).

7. Gatto, J. T. The underground history of American education: A schoolteacher's intimate investigation into the problem of modern schooling. New York, USA: Oxford Village Press (eng). 2001. 234 p. DOI: https // ww. amazon. com/Underground-History-American-Education-Investigation /dp / 0945700040/ (дата звернення: 24.02.2019).

8. Jeynes, W. H. American Educational History School, Society, and the Common Good. Thousand Oaks, CA: Sage Publications, 2007. P.23-68. DOI: https:// www. amazon.com /American-EducationalHistory-School-Society /dp/1412914213 (дата звернення: 19.02.2019).

9. A report to the senate and house appropriations subcommittees on higher education: web-site. URL: http: //www. senate. michigan.gov/sfa/Publications /HiEdApprops / HiEdApprops_ MostRecent.pdf. (Last accecced: 11.02.2019).

10. Bureau of Labor Statistics : web-site. URL: https://www.bls.gov/_(дата звернення: 11.03.2019).

11. Trends in Higher Education Reports Find Published Tuition and Fees in Grant Aid for Students Continue to Grow at Moderate Rates: web-site. URL: https://www.prnewswire.com/news-releases/trendsin-higher-education-reports-find-published-tuition-and-fees-in-grant-aid-for-students-continue-to-growat-moderate-rates_(дата звернення: 19.02.2019).

12. How to avoid default, credit damage and extra fees when you can't pay student loans: web-site. URL: https: //www. debt.com/ student-loan-debt/cant-pay-student-loans_(дата звернення: 14.02.2019).

\section{References}

1. Stoyko, O.YA. (2014). Finansova pidtrymka vyshchoyi osvity v SSHA [Financial support for higher education in the United States]. Naukovyy visnyk Uzhhorods'koho natsional'noho universytetu Scientific herald of Uzhgorod National University, 29, 213-216. Retrieved from: https://dspace.uzhnu.edu.ua [in Ukranian].

2. Romanovs'kyy, O.O. (2015). Derzhavna polityka SSHA i Velykobrytaniyi shchodo pidtrymky rozvytku vyshchoyi osvity [State policy of the United States and Great Britain to support the development of higher education]. Derzhavne upravlinnya: udoskonalennya ta rozvytok - Public administration: improvement and development, 12. Retrieved from: http://www.dy.nayka.com.ua [in Ukranian].

3. Tarasova ,O. (2011). Vyshcha osvita v SSHA: suchasnyy stan ta priorytety rozvytku [Higher education in USA: current state and development priorities]. Visnyk Natsional'noyi akademiyi Derzhavnoyi prykordonnoyi sluzhby Ukrayiny - Bulletin of the National Academy of the State Border Guard Service of Ukraine, 3. Retrieved from: http ://nbuv.gov. ua/UJRN /Vnadps_2011_3_9 [in Ukranian].

4. Kalinina, O.G. (2015). Systema upravlinnya yakistyu osvity u VNZ SSHA [Quality Management System in US Higher Education]. Candidat's thesis. Starobilsk, 168 p. [in Ukranian].

5. Vdovenko, L.O. (2018). Metodychni pidkhody otsinky efektyvnosti kredytnykh vidnosyn [Methodical approaches to assessing the effectiveness of credit relations]. Ekonomika ta suspil'stvo Economy and Society, 17, 518-523. Retrieved from http://economyandsociety.in.ua [in Ukranian]. 


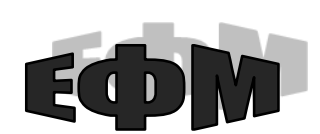

http://efm.vsau.org/

6. Floyd, D. L., Rivka, A. F., \& Ramdin, G. (2015). A retrospective of four decades of community college research. Community College Journal of Research and Practice, 1.40 (1), 5-22. Retrieved from $\mathrm{https//www.} \mathrm{tandfonline.com/doi/abs/10.1080/10668926.2015.1086707.}$

7. Gatto, J. T. (2001). The underground history of American education: A schoolteacher's intimate investigation into the problem of modern schooling. New York, USA: Oxford Village Press (eng), 234. Retrieved from: https: // ww. amazon. com/Underground-History-American-Education-Investigation /dp / 0945700040.

8. Jeynes, W. H. (2007). American Educational History School, Society, and the Common Good. Thousand Oaks, CA: Sage Publications, Inc., 23-68. Retrieved from: https // ww. amazon. com/Underground-History-American-Education-Investigation /dp / 0945700040.

9. A report to the senate and house appropriations subcommittees on higher education [web-site]. mmi. senate. michigan. Retrieved from http: //www. senate. michigan.gov/sfa/Publications /HiEdApprops / HiEdApprops_MostRecent.pdf.

10. Bureau of Labor Statistics (2019): [web-site]. Retrieved from: URL: https://www.bls.gov/.

11. More than 1 million people default on their student loans each year. mmi. cnbc.com. Retrieved from: https: //www. cnbc.com /2018/08/13/ twenty-two-percent-of-student-loan-borrowers-fall-intodefault. html.

12. How to avoid default, credit damage and extra fees when you can't pay student loans [web-site]. mmi. debt.com. Retrieved from: URL: https: //www. debt.com/ student-loan-debt /cant-pay-student-loans.

\section{Інформація про автора}

ДЖЕДЖУЛА Олена Михайлівна - доктор педагогічних наук, професор, завідувач кафедри математики, фізики та комп'ютерних технологій Вінницького національного аграрного університету (21008, м. Вінниця, вул. Сонячна, 3, e-mail: DzedzhulaO@ukr.net).

DZHEDZHULA Olena - Doctor of Pedagogical Sciences, Professor, Head of the Department of Mathematics, Physics and Computer Technologies of Vinnytsia National Agrarian University (21008, Vinnytsia, 3 Soniachna Str., e-mail: DzedzhulaO@ukr.net).

ДЖЕДЖУЛА Елена Михайловна - доктор педагогических наук, професор, заведующая кафедрой математики, физики и компьютерных технологий Винницкого национального аграрного университета (21008, г. Винница, ул. Солнечная, 3, e-mail: DzedzhulaO@ukr.net). 